\title{
Labor potential of youth for the development of ecology in the digital economy
}

\author{
Anna Balabanova ${ }^{1,{ }^{*}}$, Svetlana Petrova $^{1}$, Vita Fomenko ${ }^{1}$, and Nadezhda Keschyan ${ }^{1}$ \\ ${ }^{1}$ Sochi State University, 354000, Sochi, Russia
}

\begin{abstract}
The goal of the research is to determine the importance and relevance of youth labor potential management for the environmental industry, as well as to determine the factors and risks that affect the environmental management of labor potential. To conduct the study, analytical, statistical, comparative methods, the grouping method were used, an analysis of statistical data on the number and structure of youth was carried out, as well as an analysis of current trends, factors, risks that affect the management of the labor potential of youth in the environmental industry. The main modern factors are highlighted: population aging; disproportionate distribution of the number of young people by country; the quality of youth vocational training and education; high speed of development of digital technologies in the economy. The risks posed by digital technologies are considered separately: increasing environmental risks and requirements for the level of environmental management; high speed and unpredictability of changes; inconsistent employment; platform approach; the requirement for the study of new technologies; the structure of personnel needs is changing: the level of requirements more and more does not correspond to the level of young personnel, and the rate of change in requirements is changing faster than educational programs; labor automation leads to job cuts; digital autism and decline in professional social and intellectual skills; digital addiction.
\end{abstract}

\section{Introduction}

Digital technologies are actively changing all processes in society. For the sustainable development of territories, cities or states, youth is an important and undoubtedly always relevant object of study. Young people are the present and future of any economy. Every year, all the new problems of our time increase the importance of young people for the economy and society. The labor potential of young people in the context of an aging population, changes in the quality of labor resources of modern young people, and other new risks requires new approaches in the development and management of the youth labor market and employment processes. And of course, sustainable development is impossible without competent environmental management and development of environmental literacy among young people.

\footnotetext{
* Corresponding author: annabalabanovasochi@gmail.com
} 
Therefore, an important area of environmental management is the management of the youth labor market, the involvement of modern youth in professional development in environmental professions.

The development of a market for environmentally oriented professions will increase environmental literacy among young people, as well as provide environmental management with personnel. As studies show [1], environmental literacy combines cognitive knowledge, environmental values and environmental behavior.

When studying the problems of environmental management, both at the level of an organization or city and territorial administration, there will always be one important factor - a person $[2,3]$. The quality of labor resources, their professionalism, sufficiency and level of culture is decisive for any industry, and the quality of the labor resources of young people is a necessary condition for sustainable development [4].

And as the labor potential of youth and its impact on the economy and ecology of the territories, more and more modern problems appear $[5,6,7]$. The professional impact of educational programs on the youth labor market is changing [8].

All these changes are increasing due to the high speed of development of digital technologies in the ecological market and in the world as a whole [9, 10]. Development and change of the labor market, management of its processes are part of environmental management and attract more and more attention of researchers [11].

\section{Materials and Methods}

To conduct the study, analytical, statistical, comparative methods, the grouping method were used, an analysis of statistical data on the number and structure of youth was carried out, as well as an analysis of current trends, factors, risks that affect the management of the labor potential of youth in the environmental industry. The results of social research in the field of ecology and the environment, statistical data of state and municipal authorities, statistical organizations, the United Nations Educational, Scientific and Cultural Organization (UNESCO), Euromonitor International, the International Labor Organization and others were used as an information base.

The goal of the research is to determine the importance and relevance of youth labor potential management for the environmental industry, as well as to determine the factors and risks that affect the environmental management of labor potential.

\section{Results}

Consider the statistics of the labor potential of youth. According to the specialized agency of the United Nations Educational, Scientific and Cultural Organization (hereinafter UNESCO), at the beginning of 2019, the world's population exceeded 7.7 billion, with young people under 30 accounting for more than half of this figure $(50.5 \%)$. According to a study by Euromonitor International, $89.7 \%$ of people under 30 live in developing countries, particularly in Central Asia and Africa.

About 75 million young people in the world were unemployed in 2012, which is 4 million more than in 2007 [12].

According to the International Labor Organization in 2017, the youth unemployment rate was $13.1 \%$, which is more than 70.9 million people, and in recent years it has only increased. The share in the total number of unemployed in 2017 was $35 \%$.

In Russia, an analysis of data from the Federal State Statistics Service showed that young people aged 15 to 29 are about 24 million people or $16.5 \%$ of the total population. Analyzing the dynamics of this indicator over the past 10 years, we can conclude that there 
are negative trends. So, in 2002, the share of young people in the total population of the country, according to the All-Russian Population Census, was 23\%, and in $2010-23 \%$.

Also, in Russia, as in the world, there is an increase in youth unemployment. An analysis of data from the Federal State Statistics Service showed that the unemployment rate among young people aged 20-24 at the beginning of 2020 was $15.1 \%$, which is 3.2 times higher than the overall unemployment rate. Also, the unemployment rate among young people aged $15-19$ was $22.1 \%$, which exceeds the overall unemployment rate in Russia by 4.7 times.

Let us consider why the dynamics of these indicators are of great importance in modern world trends.

The first factor is the aging of the population, which creates additional competition in the labor market and also increases the social burden on the economically active population.

According to world statistics and the analysis of statistical indicators in Russia, the share of older people in the total population is increasing worldwide. Now the proportion of older people in Europe is $19 \%$ and $16 \%$ in North America, and by 2050 these figures will increase to $28 \%$ and $23 \%$.

Other problems that can be highlighted are:

- curbing economic growth due to a shortage of labor resources;

- capital shortages, and future fall in asset prices, as older people seek to meet their own needs and use investment funds for this;

- government budgets will begin to experience difficulties due to increased pension obligations, as well as spending on health care, long-term care, medicine, and other social obligations.

The second factor is social and political change due to the disproportionate distribution of young people across countries. $90 \%$ of all young people live in the developing world, that is, the number of young people in the world is growing, but in developed countries, it is decreasing.

According to a study in the Global Employment Trends for Youth 2020: Technology and the future of jobs report, the International Labor Organization's Global Employment Trends for Youth 2020: an increase in the number of young people who do not work, do not study, and do not acquire professional skills. In 2016, there were 259 million such young people, in 2019 their number was already estimated at 267 million (two-thirds of them, or 181 million, are young women), and in 2021 it is projected to grow to 273 million. And even if we consider the number of these young people in relation to the increase in the number of the entire population, this negative trend persists: in $2015-21.7 \%$, in $2020-$ $22.4 \%$.

The third factor is the quality of youth vocational training and education. The quality of labor force training is not keeping pace with the growth of its quantity, especially in developing countries. This creates additional social problems such as:

- poverty and inequality. There is a proportional relationship between low youth incomes and inequality in society. For example, in 2012, rising youth unemployment increased inequality (measured by the Gini coefficient) by 4 percentage points in all developed countries and by 8 percentage points in Greece, Ireland, Italy, Portugal and Spain. [13];

- work in the informal economy. According to the International Labor Organization, three out of every four young people in the world work in informal employment, while three out of five adults are employed. In developing countries, this figure rises to 19 out of 20 young women and men;

- political instability of areas where there is a lack of education for young people;

- increased risk of future environmental problems due to environmental illiteracy of the population; 
- lack of professional staff in the environmental sector, and most importantly the level of environmental management.

Next, we will consider the factors that affect the environmental management of the labor potential of youth in the digital economy.

The fourth factor is digital technologies in the economy. Digital technologies create new threats to the management of the young labor market and the environment in general:

- increasing environmental risks and requirements for the level of environmental management. Modern technologies create new risks for the environment, for example, high-tech waste, more hazardous production processes, the availability of natural locations for more people and organizations, and others;

- high speed and unpredictability of changes. The modern world creates new requirements for young people, such as high adaptability, flexibility, and the need for education.

- intermittent employment. Many young people start their working life with temporary employment, realizing that they may never get stable employment. At the same time, such work is associated with significant risks: low income, lack of a guarantee of permanent employment, stable income, access to work-related benefits and benefits.

- platform approach. More and more young people looking for work and young entrepreneurs are turning to the Internet, that is, where a business is done on network platforms or "to order". There you can find a variety of new forms of employment, such as the so-called crowd working, that are flexible and expand earning opportunities.

- the requirement for the study of new technologies. Young people learn new technologies more easily than older workers and are increasingly using them as a means of earning money, although this process proceeds differently in different regions, depending on the spread and availability of digital technologies.

- the structure of staffing requirements is changing. The demand for mid-level specialists is declining, while the demand for highly skilled and unskilled workers, on the contrary, is growing. This change is leading to an increasing division in the labor market. The demand for highly skilled youth is growing especially in high-income countries, while the demand for unskilled labor is increasing in developing and emerging market economies. At the same time, the employment of low-skilled young workers is declining in most countries, regardless of the level of development. Also in the study "Global Trends in Youth Employment in 2020: Technology and Tomorrow's Jobs," the International Labor Organization found that the share of young people with higher education in the workforce is growing faster than the demand for workers with diplomas, and this leads to a decrease payment of their labor.

In 2020, 1.5 million people entered the Russian labor market for the first time (738 thousand college graduates and about 500 thousand masters and bachelors. Plus 200-300 thousand school graduates who did not plan to enroll in universities and colleges).

- automation of labor leads to a reduction in jobs. In standard economic industries, more and more jobs are being automated because it is economically viable. Labor automation also creates new jobs, but in fewer numbers and with high professional requirements. As a result, competition in the labor market is growing, unemployment is increasing.

- digital autism and decline in professional social and intellectual skills. A number of studies show results in which modern youth are increasingly suffering from "digital autism". Smartphones and social media take users into "two-dimensional space", draining their memory and destroying their brains, while social skills atrophy. When people become isolated in this space, they become autistic and give up real life. All this negatively affects the processes of youth employment in modern conditions.

According to M. Spitzer's research, it can be seen that digital technologies provide many advantages, but their incorrect use, lack of control over changes in learning processes create 
many new threats to education, and, accordingly, the quality of future specialists $[14,15$, 16].

For example, he identifies the following risks:

- typing impairs reading and writing;

- reading and writing impairment impairs learning and memory;

- information technologies lead to superficial processing of information;

- the use of WLAN in lecture halls leads to a decrease in student performance due to increased distraction;

- IT causes IT addiction in a significant number of students (up to 20\%);

- social skills decline.

For any human activity, including environmental management, the most important factor is a person. The effectiveness of environmental management and the implementation of measures, environmental programs of states and the world directly depends on the quality of personnel.

Let us list the main factors and risks that increase the importance and need for the development and management of the labor potential of youth and the active employment of youth in the environmental sphere of activity (fig.1):

- population aging;

- disproportionate distribution of the number of young people by country;

- quality of vocational training of youth and education;

- high speed of development of digital technologies in the economy;

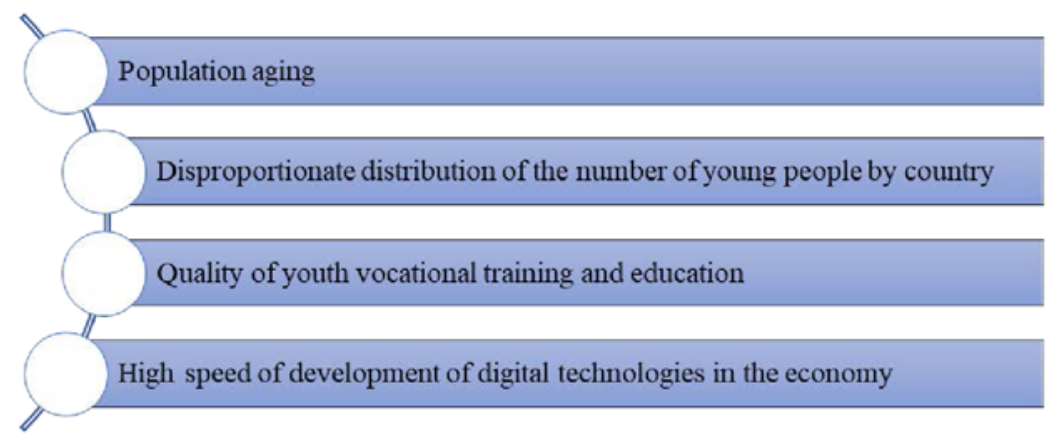

Fig. 1. Factors that increase the relevance of youth workforce management for the environmental industry.

Let's highlight the risks for each factor (tabl.1):

Table 1. Factors and risks that increase the relevance of youth workforce management for the environmental industry.

\begin{tabular}{|c|l|l|}
\hline № & \multicolumn{1}{|c|}{ Factors } & \multicolumn{1}{c|}{ Risks } \\
\hline 1. & Population aging & $\begin{array}{l}\text { - additional competition in the labor market; } \\
\text { - social burden on the economically active population; } \\
\text { - curbing economic growth due to a shortage of labor resources; } \\
\text { - capital deficit, and future fall in asset prices; } \\
\text { - government budgets will begin to experience difficulties due to an } \\
\text { increase in pension obligations, as well as spending on health care, } \\
\text { long-term care, medicine, and other social obligations. }\end{array}$ \\
\hline 2. & $\begin{array}{l}\text { Disproportionate } \\
\text { distribution of the } \\
\text { number of young } \\
\text { people by country }\end{array}$ & $\begin{array}{l}\text { - social and political changes; } \\
\text { - hard-to-control migrations; } \\
\text { - the number of young people who do not work, do not study and do } \\
\text { not acquire professional skills is increasing. }\end{array}$ \\
\hline 3. & The quality of & - poverty and inequality; \\
\hline
\end{tabular}




\begin{tabular}{|l|l|l|}
\hline $\begin{array}{l}\text { youth training and } \\
\text { education }\end{array}$ & $\begin{array}{l}\text { - work in the informal economy; } \\
\text { - political instability of territories where there is a lack of education } \\
\text { for young people; } \\
\text { - increased risk of future environmental problems due to } \\
\text { environmental illiteracy of the population; } \\
\text { - lack of professional staff in the environmental sector, and most } \\
\text { importantly the level of environmental management. }\end{array}$ \\
\hline 4. & $\begin{array}{l}\text { High speed of } \\
\text { development of } \\
\text { digital } \\
\text { technologies in the } \\
\text { economy }\end{array}$ & $\begin{array}{l}\text { - increasing environmental risks and requirements for the level of } \\
\text { environmental management; } \\
\text { - high speeds and unpredictability of changes; } \\
\text { - inconsistent employment; } \\
\text { - platform approach; } \\
\text { - the requirement for the study of new technologies; } \\
\text { - the structure of personnel needs is changing: the level of } \\
\text { requirements is more and more inconsistent with the level of young } \\
\text { personnel, and the rate of change in requirements is changing faster } \\
\text { than educational programs; } \\
\text { - automation of labor leads to a reduction in jobs; } \\
\text { - digital autism and decline in professional social and intellectual } \\
\text { skills; } \\
\text { - digital addiction. }\end{array}$ \\
\hline
\end{tabular}

To manage the labor potential of youth, this concept can be assessed from two sides:

- from the quantitative point of view: as the number of individuals within the boundaries of a given economic territory, which at the time of accounting refers to the labor force;

- from the qualitative point of view: as the socio-economic characteristics of the labor force: qualifications, specialization, marital status, educational level, specialty, etc.

\section{Discussion}

What is the role of the labor potential of youth for the development of the environment in the digital economy? The study of modern trends, socio-economic problems, allows us to highlight the main modern factors that allow us to conclude that the management of the labor potential of young people is one of the most important tasks for the sustainable development of the world and modern environmental management. The main factors can be identified: aging of the population; disproportionate distribution of the number of young people by country; the quality of youth vocational training and education; high speed of development of digital technologies in the economy.

\section{Conclusions}

Young people can become a strong positive factor in the development of the economy and environmental activities of society, but only if young people are provided with the necessary knowledge and opportunities. In particular, young people need to get the education and skills they need, and they need access to the labor market.

It is important for environmental management to create a youth employment policy that takes into account the rapid changes in the world of work in a digital world and an aging population. And it is especially important to take into account the risks posed by the modern digital economy: increasing environmental risks and requirements for the level of environmental management; high speed and unpredictability of changes; inconsistent employment; platform approach; the requirement for the study of new technologies; the structure of personnel needs is changing: the level of requirements more and more does not correspond to the level of young personnel, and the rate of change in requirements is 
changing faster than educational programs; labor automation leads to job cuts; digital autism and decline in professional social and intellectual skills; digital addiction.

One of the areas of environmental management should be investments in continuous environmental education systems, the development of digital literacy of personnel, and the implementation of sectoral strategies that contribute to the spread of decent work. Also important are employment and adaptation programs in the labor market of modern youth. Comprehensive strategic programs and flexible training systems are needed, developed through dialogue with governments, workers and employers.

Not enough jobs are being created for young people, which means that the potential of millions of people is not being adequately tapped. If we want to solve the problems arising in connection with digital development, climate change, growing inequality, demographic shifts, and modern environmental problems, as well as create conditions for the development of the environmental sphere, then the potential of young workers must not be overlooked and underestimated.

\section{References}

1. M. Maurer, F.X. Bogner, Studies in Educational Evaluation 65 (2020)

2. A. Balabanova, N. Keschyan, T. Borisova, E. Hachemizova, E3S Web of Conferences 91, 08019 (2019)

3. A. Balabanova, N. Keschyan, E3S Web of Conferences 135, 04013 (2019)

4. M. Egorova, O. Garanina, S. Petrova, I. Okhrimenko, Opcion 35, 1446-1474 (2019)

5. N. Papadakis, E. Amanaki, M. Drakaki, S. Saridaki, International Journal of Educational Research 99, 101503 (2020)

6. G. Liotti, Structural Change and Economic Dynamics 54, 150-162 (2020)

7. A. Bagchi, J.A. Paul, Socio-Economic Planning Sciences 64, 9-20 (2018)

8. A. Muja, L. Blommaert, M. Gesthuizen, M.H.J. Wolbers, Research in Social Stratification and Mobility 64, 100437 (2019)

9. J. Picatoste, L. Pérez-Ortiz, S.M. Ruesga-Benito, Telematics and Informatics 35(4), 1031-1038 (2018)

10. A.I. Leonow, M.N. Koniagina, S.V. Petrova, S.Y. Kerimkhulle, V.G. Shubaeva, Espacios 40(38) (2019)

11. Ch. Bhattacharyya, M.R. Gupt, International Review of Economics \& Finance 72, 2944 (2021)

12. Global Employment Trends for Youth, International Labor Office 7 (2012)

13. M. Matsumoto, M. Hengge, I. Islam, International Labor Office 7 (2012)

14. M. Spitzer, Education 3(3-4) (2014)

15. M. Spitzer, Trends in Neuroscience and Education 4(4), 87-91 (2015)

16. M. Spitzer, Trends in Neuroscience and Education 2(3-4), 95-99 (2013) 